\title{
ЗАСАДИ СТВОРЕННЯ ЄДИНОЇ ДЕРЖАВНОЇ СИСТЕМИ ІНФОРМАЦІЙНОГО ЗАБЕЗПЕЧЕННЯ ЗАКЛАДІВ ОХОРОНИ ЗДОРОВ'Я
}

\author{
О. П. Мінцер, Л. Ю. Бабінцева, М. В. Банчук \\ Національна медична академія післядипломної освіти імені П. А. Шупика
}

\begin{abstract}
Розглянуто засади нової єдиної інформаційної системи охорони здоров'я (ЄІСОЗ). У системі, на відміну від існуючих аналогів, розглянуто комплексне відображення всіх факторів, які впливають на стан здоров'я, в тому числі навколишнє середовище, фрармацевтичне навантаження тощо.

Виділено принципи створення ЄІСО3, серед яких найважливішим вважають обов'язкову реалізацію дуальності (наявності стаціонарної та мобільної - медичного електронного паспорта громадянина - частин).
\end{abstract}

Ключові слов+: державне управління, єдина інформаційна система охорони здоров'я, інформаційне середовище, інформаційний ресурс, управління інтегрованою системою охорони здоров'я.

\section{ПРИНЦИПЫ СОЗДАНИЯ ЕДИНОЙ ГОСУДАРСТВЕННОЙ СИСТЕМЫ ИНФОРМАЦИОННОГО ОБЕСПЕЧЕНИЯ УЧРЕЖДЕНИЙ ЗДРАВООХРАНЕНИЯ}

\author{
О. П. МИНЦЕР, Л. Ю. Бабинцева, Н. В. БАНМК
}

Национальная медицинская академия последипломного образования имени П. А. Шупика

\begin{abstract}
Рассмотрены принципы новой единой информационной системы здравоохранения (ЕИСЗО). В системе, в отличии от существующих аналогов, рассматривается комплексное отображение всех факторов, влияющих на состояние здоровья, в том числе окружающая среда, фрармацевтическая нагрузка и тому подобное.

Выделены также принципы создания (ЕИСЗО), среди которых важнейшим считается обязательная реализация дуальности (наличие стационарной и мобильной медицинского электронного паспорта гражданина частей).

ключєвзє слов+: государственное управление, единая информационная система здравоохранения, информационная среда, информационный ресурс, управление интегрированной системой здравоохранения.
\end{abstract}

\section{PRINCIPLES OF FORMATION OF UNIFIED STATE SYSTEM OF INFORMATIVE PROVIDING OF HEALTH CARE INSTITUTIONS}

\author{
O. P. Mintser, L.Yu. Babintseva, M. V. Banchuk \\ National Medical Academy of Post-Graduate Education by P. L. Shupyk
}

Principles of the new unified informative system of health care (UISHC) are considered. In the system unlike existent analogues the complex reflection of all factors influencing on the state of health, including environment, pharmaceutical factors etc. are under discussion.

Principles of formation of UISHC among which the most important is realization of duality (availability of stationary and mobile к medical electronic passport of a citizen) are also defined.

+eA BorCs: state a dministration, unified informative system of health care, informative environment, informative resource, management of integrated health care system.

Вступ. Загальноприйнято, що від рівня інформатизації охорони здоров'я та якості роботи з інформацією залежить ефективність надання першої допомоги та наступного лікування пацієнта. Для забезпечення належної якості медичної допомоги існує нагальна потреба в накопиченні й аналізі даних впродовж тривалого періоду, застосуванні електронних експертних систем.
Варто підкреслити, що проблемі дослідження процесів інформатизації в системі охорони здоров'я присвячено тисячі досліджень. Мабуть, жодна галузь не витрачала стільки сил і коштів, скільки витрачено в медицині.

При цьому лише менше 10 \% закладів охорони здоров'я застосовують у своїй діяльності системи ведення електронної історії хвороби, менше 5 \% осна-

(C) О. П. Мінцер, Л. Ю. Бабінцева, М. В. Банчук 
щені засобами телемедицини. Використовувані прикладні системи не дозволяють повною мірою забезпечити підтримку рішень актуальних завдань як в галузі управління, так і безпосереднього надання населенню медичної допомоги. Спостерігається низький рівень нормативного та методичного забезпечення процесу інформатизації охорони здоров'я.

Перелічені проблеми є наслідком несистемності розвитку інформаційно-комунікаційних технологій у медицині, орієнтованості на розв'язання локальних і приватних завдань, відсутності установки на забезпечення безперервності та комплексності процесів охорони здоров' я.

Слабо розвинена система галузевих стандартів і технічних регламентів. Наявні на ринку прикладні рішення для медичних організацій переважно орієнтовані на роботу зі слабоструктурованими даними. Електронні документи, що зберігаються, і записи, за рідкісним винятками, є вторинними щодо паперових і не мають юридичної значущості.

У рамках управління охороною здоров'я реалізовані в основному процеси узагальнення та надання на вищий рівень агрегованої інформації за встановленою формою. При цьому відсутня можливість перевірки валідності такої інформації.

Сьогодні у світовій практиці накопичений значний досвід застосування інформаційно-комунікаційних технологій в охороні здоров'я. У США, Канаді, Свросоюзі та багатьох інших країнах національні програми інформатизації охорони здоров'я реалізовуються вже понад п'ять років.

Отже, з одного боку, намітилося істотне відставання від розвинених країн у цьому питанні. 3 іншого боку, наявні вітчизняні розробки та доступність інформації про зарубіжний досвід дозволять здійснити рішучий прорив на якісно новий рівень використання інформаційно-комунікаційних технологій в управлінні охороною здоров'я та надання медичної допомоги у стисліші терміни і з меншими витратами бюджетних коштів, порівняно з зарубіжними аналогами.

Зазначені проблеми свідчать про необхідність корінної зміни підходу до інформатизації охорони здоров'я, посилення координуючої ролі держави та створення єдиного інформаційного простору у системі охорони здоров' я.

Метою роботи є визначення та обгрунтування нових рішень зі створення медичної інформаційної системи на рівні країни з використанням світового досвіду та власних досліджень.

Результати та їх обговорення. Постановка завдання. Окрім відносної незабезпеченості закладів охорони здоров'я комп'ютерною технікою, використовувані прикладні системи не дозволяють забезпечити підтримку рішень актуальних завдань як у площині управління галуззю, так і в системі безпосереднього надання медичної допомоги. Спостерігається надзвичайно низький рівень нормативного та методичного забезпечення процесів інформатизації охорони здоров'я. На ринку інформатизації охорони здоров'я в Україні працюють десятки операторів, які пропонують практично протилежні та несумісні рішення. Внаслідок відсутності єдиних принципів інформатизації системи охорони здоров'я держава щорічно втрачає десятки мільйонів гривень.

Обгрунтовуючи нові підходи до інформатизації галузі, важливо відокремити три групи стратегічних завдань.

У системі управління охороною здоров'я найзначущішими є такі питання:

- планування обгрунтованих витрат на надання гарантованих обсягів медичної допомоги відповідно до стандартів якості;

- контроль за ефективністю витрачання бюджетних коштів на медичне і лікарське обслуговування населення, а також за обігом лікарських засобів i виробів медичного призначення;

- оптимізація розподілу та завантаження людських і матеріальних ресурсів в охороні здоров'я з урахуванням потреб галузі;

- своєчасне застосування ефективних заходів щодо забезпечення санітарно-епідеміологічного благополуччя населення.

У системі безпосереднього надання медичної допомоги найсуттєвішими є питання інформаційного забезпечення:

- профілактики та раннього діагностування захворювань, своєчасного надання медичної допомоги пацієнтам різних груп ризику;

- ефективного використання наявних ресурсів у системі охорони здоров'я, включаючи високотехнологічне медичне устаткування, вартісні лікарські засоби, донорські матеріали та препарати на їх основі;

- підтримки прийняття лікарських рішень, у тому числі за рахунок надання оперативного доступу до повної і достовірної інформації про здоров'я пацієнта, впровадження автоматизованих процедур перевірки відповідності обраного лікування стандартам надання медичної допомоги, перевірки відповідності призначених лікарських засобів на предмет їх можливої взаємодії;

- отримання лікарських консультацій особами, які не мають можливості відвідувати медичні установи; 
- якісної освіти, безперервного навчання, проведення ефективних наукових досліджень, а також активної професійної взаємодії медичних і фармацевтичних фахівців.

У системі взаємодії органів управління охороною здоров'я, медичних організацій з населенням і організаціями 3 питань охорони здоров'я найзначущішими є питання: підвищення рівня медичної грамотності громадян, а також рівня інформаційної грамотності медичних і фармацевтичних працівників; повнішого й ефективнішого залучення громадян до процесу забезпечення здорового способу життя; підвищення точності дотримання пацієнтами отриманих призначень за рахунок використання інформаційно-комунікаційних технологій (IКТ).

Засади створення Єдиної інформаційної системи охорони здоров 'я. ЄICO3 можна визначити як структуру, в якій функціонують 5 сегментів та діють 4 базові принципи.

Серед сегментів відокремлюємо: інформаційне відображення здоров'я населення; віддзеркалення медичної допомоги з позицій забезпечення іiї якості; управління трудовими ресурсами; відображення характеристик середовища, де мешкає громадянин (насамперед, навколишнього середовища); віддзеркалення фармацевтичного забезпечення галузі й обгрунтованого застосування лікарських засобів.

Серед базових принцииів виділяємо: обов'язкову реалізацію дуальності (наявності стаціонарної та мобільної - медичного електронного паспорта громадянина України - частин) ЄICO3; створення та впровадження медичних стандартів (професійної мови, архетипів, шаблонів, класифікацій тощо); створення та впровадження інформаційних стандартів; забезпечення функціонування єдиного медичного простору.

Розглянемо сегменти ЕICO3.

Концептуальні положення сегмента інформаиіийого відображення здоров 'я населення. Для досягнення здоров'я необхідно досліджувати феномен здоров'я, знати його закономірності та використовувати їх для досягнення здоров'я. Але врахуємо, що здоров'я не виділене в предмет дослідження жодною офіційно затвердженою наукою а, отже, не визначена сутність здоров'я та немає його дефініції, що можна було б використовувати в практичній діяльності. Існуючі на сьогодні понад 150 дефініцій здоров'я - від «благополуччя» (ВОО3) до «рівноваги 3 навколишнім середовищем» $\mathrm{i}$ «оптимального функціонування органів і систем» не дають достатньої інформації, придатної для формування управлінських дій, про керований об'єкт.
Численні спроби охарактеризувати індивідуальне здоров'я прямими показниками та побудувати шкалу «позитивного» здоров'я не дали результату з однієї простої причини - на сьогодні не розроблена теорія індивідуального здоров'я, а всі його дефініції грунтуються на формулюваннях, в яких відсутні елементи операціональності. Наприклад, в ухваленому Законі України «Про внесення змін до основ законодавства України про охорону здоров'я» знову використовується формулювання ВООЗ: «Здоров'я - стан повного фізичного, психічного та соціального благополуччя, а не тільки відсутність хвороб і фізичних вад». Термін «благополуччя» не відповідає умові «операціональності», і тому здоров'я ніяк не може бути ідентифіковане (найбільш «благополучними» за своїм світосприйняттям є хворі на сифіліс із 3 стадією; про це писав ще В. Вересаєв у «Записках лікаря»), і тому лікар знову встановлюватиме діагноз «здоровий» методом виключення - за відсутністю ознак хвороби.

Практика показує, що в останні десятиліття складно зустріти людину без будь-яких ознак патологічного процесу. Отже, альтернативна оцінка «здоровий» або «хворий» - недостатня; необхідно встановити, наскільки здоровий (рівень здоров'я) і наскільки хворий індивід (клінічний діагноз). Саме від взаємозв'язку процесів здоров'я і хвороби залежить прогноз стану конкретного індивіда - одужання, перехід захворювання в хронічну форму, смерть.

Для Закону України «Про внесення змін до основ законодавства України про охорону здоров 'я» (2011) нами (разом з проф. Г. Л. Апанасенком) запропоновано таке визначення здоров'я: «Здоров'я - стан, який забезпечує виконання людиною своїх біологічних (виживання та репродукція) і соціальних фунцій». Поняття «виживаність (життєздатність)» і «репродукція» можуть бути ідентифіковані та кількісно охарактеризовані. Таким же чином, може бути охарактеризований ступінь соціалізації індивіда. Це дає можливість «управляти» здоров'ям.

Поява простої методики «вимірювання» здоров'я дозволила нам проводити дослідження популяцій, що привело до відкриття нових феноменів:

- чим нижчий рівень здоров'я, тим більша вірогідність розвитку ендогенних чинників ризику розвитку хронічних соматичних захворювань (ХC3) та їх маніфестації;

- існує «безпечний» рівень здоров'я (БРЗ), вище якого не реєструються ні ендогенні чинники ризику, ні форми захворювання, що маніфестують; йому надана кількісна характеристика. Очевидно, що саме БРЗ є основою первинної профілактики ХС3; він же 
- реальний інструмент попередження смерті, наприклад, школярів і студентів при заняттях фізкультурою;

- при виході індивіда 3 «безпечної зони» здоров'я виявляється феномен «саморозвитку» патологічного процесу без зміни сили чинника, що діє. Описані механізми цього феномену;

- повернення практично здорового індивіда в «безпечну зону» здоров'я кваліфікується нами як «превентивна реабілітація».

Концептуальні положення сегмента управління якістю надання медичних послуг. Для аналізу якості надання медичної допомоги (ЯМД) потрібні системні інтегральні показники. Нами було запропоновано квадрупольну модель відображення процесу надання медичної допомоги, що складається з чотирьох кластерів.

Кластер 1. Інтегральна оцінка (суб'єктно-орієнтована модель) ЯМД.

Kритерї: 1) оцінка стану здоров'я (кількісні показники рівня здоров'я); 2) оцінка тяжкості стану (кількісні показники обсягу допомоги); 3) оцінка ризику И ідентифікація загрози виникнення ускладнень або рецидивів захворювання (показники факторів ризику та самі ризики); 4) загальна професійна оцінка якості медичної допомоги (показники одужання).

Кластер 2. Технологічна оцінка (процесно-орієнтована модель) яМД.

Kpитерї: 1) оцінка індикаторів (показники процесу та результатів його впровадження); 2) оцінка трендів (статистичні показники), оцінка факторів впливу (показники дієвості ресурсів); 4) оцінка організаційних змін (показники результативності).

Кластер 3. Методологічна оцінка (об'єктно-орієнтована модель) ЯМД.

Критеріi: 1) професійна оцінка (показники професійної експертизи); 2) адміністративна оцінка (статистичні показники); 3) індустріальна оцінка (інтегральні показники); 4) еталонна оцінка (показники відповідності наданої допомоги існуючим стандартам і протоколам).

Кластер 4. Оцінка ЯМД за окремими додатковими критеріями.

Критеріi: 1) соціальна оцінка (показники задоволеності); 2) експертна оцінка (індивідуальні показники); 3) оцінка дефектів надання ЯМД (показники дефектури надання медичної допомоги); 4) оцінка локальних умов (показники внутрішньолікарняної ефективності).

Нами виділено:

- соціальний підкластер: задоволеність пацієнта, лікаря, медичного працівника; створення гуманних умов хворому в термінальній стадії захворювання; міра соціальної (соціально-економічної) адаптації пацієнта.

- «експертний» підкластер: порушення договірних обсягів медичної допомоги застрахованим громадянам; скарги та заяви застрахованих громадян, страхувальників, відділів захисту прав споживачів тощо на порушення договірних зобов'язань при наданні медичної допомоги; відхилення від нормативів витрат на забезпечення пацієнтів лікарськими засобами, виробами медичного призначення та дієтичним харчуванням, встановленим на певний час недотриманням правил і умов безпеки при наданні медичної допомоги застрахованим громадянам; випадки повторних госпіталізацій тощо.

- «виробничий» підкластер, що об'єднує лікувальні та діагностичні дефекти надання медичної допомоги: несвоєчасна діагностика захворювань, неадекватне лікування; необгрунтовано тривале перебування пацієнта в приймальному відділенні без надання належної медичної допомоги, недіагностовані захворювання; проведення не призначених (не показаних) лікувальних маніпуляцій тощо.

Пропонується використання коефіцієнта досягнення результату (КДР), що визначається як співвідношення реально досягнутої суми балів (за вирахуванням балів за показниками дефектів) до суми оцінок нормативних (прийнятих у галузі чи окремих закладах охорони здоров'я) значень показників:

$$
\begin{aligned}
& \mathrm{KДP}=\left[\left(\mathrm{O \Pi P}_{1}+\mathrm{O \Pi P}_{2}+\mathrm{O \Pi P}_{3}+\ldots \mathrm{O} \Pi \mathrm{Pn}\right) \times\right.
\end{aligned}
$$

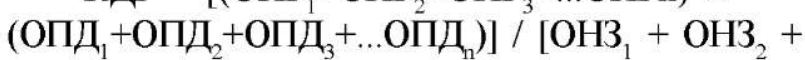

$$
\begin{aligned}
& \left.\ldots+\mathrm{OH}_{3}\right] \text {, }
\end{aligned}
$$

де ОПР ОПД - оцінка показників дефектів надання медичної допомоги, ОНЗ показників результативності.

Обгрунтовані також загальний функціонал (У ) ЯМД і функціонал ЯМД другого рівня $\mathrm{Y}_{\phi}$ :

$$
\mathrm{Y}_{3}=\mathrm{k}_{1} \mathrm{x}_{1}+\mathrm{k}_{2} \mathrm{x}_{2}+\ldots \ldots+\mathrm{k}_{\mathrm{i}} \mathrm{x}_{\mathrm{i}}+\mathrm{R}+\mathrm{D},
$$

де $\mathrm{x}_{1}$ - найбільш інформативні (важливі) показники якості медичної допомоги; к - коефіцієнти, що підбираються під час "навчання", R - сталість тренду показників, D - узгодженість показників у багатовимірному просторі,

$$
\mathrm{Y}_{\mathrm{\phi}}=\mathrm{k}_{1} \mathrm{x}_{1}+\mathrm{k}_{2} \mathrm{x}_{2}+\ldots \ldots+\mathrm{k}_{\mathrm{j}} \mathrm{x}_{\mathrm{j}}+\mathrm{R}+\mathrm{D}
$$

де $\mathrm{x}_{\mathrm{i}}$ - окремі показники якості медичної допомоги; к - коефіцієнти кореляцій між кластерами показників, R - сталість тренду показників, D - узгодженість показників у багатовимірному просторі.

Для оцінювання можливості застосування запропонованих функціоналів системних висновків щодо 
ЯМД на інституціональному рівні зіставлялися висновки експертів і значення функціоналів. Обчислювався коефіцієнт кореляції. Виявилося, що його значення коливається в проміжку 0,65 - 0,8. Аналіз відносно невисоких коефіцієнтів кореляції показав, що спостерігається суттєво неоднорідна множина кореляційних взаємозв'язків. Найнижчі значення коефіцієнтів кореляції спостерігаються для індикаторних оцінок. Дійсно, показники наступності, дієвості тощо мають надто суб'єктивний характер і потребують якнайшвидшої стандартизації.

Загальні принципи структури сегмента управління трудовими ресурсами. Стан здоров'я населення завжди виступає як один із регуляторів і показників соціального розвитку країни, оскільки формує та підтримує доктрину життєздатності суспільства. Оптимальне забезпечення населення закладами охорони здоров'я є основною передумовою реалізації стратегії пріоритетного розвитку медичної допомоги, водночас від рівня підготовки лікарів i медичних сестер залежить якість надання медичної допомоги та послуг населенню.

Всесвітньою організацією охорони здоров'я визнано, що "сектор охорони здоров'я, у якому зайнято понад 10 \% від загальної кількості трудових ресурсів у світі, фактично виступає в якості стабілізуючої галузі. Так само як і в США, в Свропі охорона здоров'я - це один із небагатьох економічних секторів, де все ще створюються нові робочі місця".

Центральне місце будь-якої системи охорони здоров'я займають кадрові ресурси, що відіграють вирішальну роль у зміцненні здоров'я населення. Ефективність систем охорони здоров'я й якість медичних послуг прямо залежать від ефективної діяльності медичного персоналу, а також його професійної компетентності та мотивації. Проблеми, що пов'язані 3 кадровими ресурсами охорони здоров'я, постійно визнаються ООН як найбільша перешкода на шляху досягнення цілей тисячоліття в галузі розвитку. Тому вкрай важливим є моніторинг функціонування кадрових ресурсів при тотальній інформатизації охорони здоров'я.

Мета кадрової політики у вирішенні глобальних проблем охорони здоров'я - підготувати необхідних працівників відповідної кваліфікації, забезпечити їх відповідним місцем праці, зберігаючи гнучкість для реагування на кризові явища, вирішуючи нагальні проблеми та передбачаючи події у майбутньому. Шаблонний підхід у цьому випадку працювати не буде, оскільки ефективні стратегії в сфері кадрових ресурсів мають відповідати унікальним історичним умовам і ситуації кожної країни". Тому основою стратегії розвитку кадрових ресурсів є тактичне, національно-варіативне вирішення динамічних проблем розвитку кадрових ресурсів, що охоплює усю їхню професійну діяльність від підготовки, початку і завершення, і які враховують історичні, соціальні, культурні, науково-технічні особливості країни. Це має бути вирішено шляхом інформаційного моніторингу діяльності галузі.

Характерною для більшості розвинених країн світу $\epsilon$ також наявність обов'язкової системи сертифікації та ліцензування лікарської діяльності, що має на меті захистити населення від некваліфікованих дій лікарів — фахівців однісї з найбільш критичних та соціально значущих спеціальностей щодо професійних помилок. Результати подібної сертифікації мають найти своє відображення при зіставленні якості медичної допомоги та кваліфікації лікарів.

3 точки зору політики управління даною стратегією розвитку кадрів необхідно забезпечити баланс між вимогами ринку праці та обов'язками держави щодо гарантування якості послуг як на навчання i підготовку фахівців, так і якості медичних послуг, що зрештою впливає на стан здоров'я населення країни.

Отже, важливість розроблення та впровадження в Україні сучасної й ефективної системи віддзеркалення роботи медичних фахівців при інформатизації охорони здоров'я не викладає сумніву, більше того, виступає як складова національної безпеки країни.

Загальні приничии структури сегмента відображення характеристик навколишнього середовища. Головна мета реєстрації показників багатокомпонентної сукупності природних явищ, що постійно зазнає різноманітних динамічних змін - оцінювання іiі впливу на людину та популяцію в цілому. Всебічне спостереження за станом цієї сукупності явищ є досить складним питанням, вирішити яке можна лише шляхом виділення 3 усього моніторингу окремих блоків.

Подібна фіксація показників навколишнього середовища ЄICO3 надає можливості створення біомедичного моніторингу та як наслідок, визначення стану біотичної складової біосфери та іiі реакції на антропогенний вплив. Зрозуміло, що особливе місце належить генетичному моніторингу - спостереження за можливими спадковими змінами.

Для спостереження за станом здоров'я населення повинна використовуватися система показників, що відбивають основні типи екологічних реакцій людини на навколишнє середовище: інфекційних, алергенних, мутагенних, психогенних тощо. 
Найбільш відпрацьованими для використання в цій системі є нормативи гранично допустимої концентрації (ГДК) забруднюючих речовин в атмосферному повітрі, водному середовищі, грунтах і живих організмах.

Формування інформаційного середовища. Інформаційне середовище забезпечує побудову інформаційного суспільства в країні і входження ії у світову інформаційну спільноту.

Прийнято вважати, що процес формування інформаційного середовища суспільства включає комплекс передумов, умов, чинників і категорій, покликаних забезпечити якісно найкращі умови використання наявних і створюваних інформаційних ресурсів з урахуванням автоматизованих способів їх обробки i використання в цілях соціально корисного процесу.

Розглядання пов 'язаних з цим процесом проблем припускає аналіз комплексу організаційно-правових, економічних аспектів і соціальних передумов та умов формування інформаційного середовища, а, отже, інформатизації охорони здоров'я та суспільства в цілому.

Очевидно, що процес формування інформаційного середовища для охорони здоров'я нерозривно пов'язаний i залежить від цілого ряду категорій і понять, що безпосередньо впливають на процес інформатизації взагалі.

Зазвичай у складі інформаційного середовища розглядають такі основні категорії:

- інформаційний ресурс (IP) суспільства, як сукупність інформаційних ресурсів різного характеру документів (у тому числі тих, що знаходяться в різних інформаційних системах), інформації, що знаходиться у базах і банках даних. Коли йдеться про створення інформаційного середовища для охорони здоров'я, необхідно особливу увагу приділити принципам забезпечення відомостей, їх отриманню і аналізу; поширенню і використанню, критеріям надійності і своєчасності інформації; значенню детермінант здоров'я, даних про результати функціонування системи охорони здоров'я (СО3);

- інформаційно-комунікаційна інфраструктура, що включає: територіально розподілені державні, недержавні та корпоративні комп'ютерні і телекомунікаційні мережі, системи спеціального призначення загального користування, канали передавання даних, засоби комутації й управління інформаційними потоками;

- інформаційні, комп'ютерні та телекомунікаційні технології - базові, прикладні і такі, що забезпечують інформаційні системи та засоби їх реалізації;

- інформаційну індустрію - науково-виробничий потенціал в галузях зв'язку, телекомунікацій, інформатики, обчислювальної техніки, поширення і доступу до інформації;
- ринок інформаційних технологій, засобів зв'язку, інформатизації і телекомунікацій, інформаційних продуктів і послуг;

- соціальний інтелект - організаційні структури, включаючи кадри, спроможні забезпечити створення, функціонування і розвиток національної інформаційної інфраструктури;

- систему забезпечення інформаційної безпеки (захисту);

- систему інформаційного законодавства.

Інформаційні ресурси будь-якої держави є її національним надбанням. Кількість, якість і доступність IP вже зараз багато в чому визначають рівень розвитку суспільства і його статус у світовій спільноті.

Поняття інформаційного середовища, як і багато інших, можна трактувати як в широкому, так і у вузькому ceнci. 3 позицій існування інформаційного ресурсу інформаційне середовище у вузькому сенсі - це накопичений у суспільстві інформаційний ресурс. Інформаційне середовище в широкому сенсі - це активізований, введений у дію інформаційний ресурс.

Одним із найважливіших показників успішного руху по дорозі до інформаційного суспільства є міра доступності ресурсів користувачеві. Це, в першу чергу, стосується системи охорони здоров'я. Саме за цим показником Україна досі відстає від розвинених країн світу.

Інформаційні системи, реалізовані в інтересах управління охороною здоров'я на рівні регіону, головним чином, забезпечують функціонування прийнятої в регіоні моделі розрахунків за допомогу, надану за програмою обов'язкового медичного страхування, а також процеси адміністративно-господарського управління ресурсами установ охорони здоров'я. При цьому у більшості випадків відсутнє сполучення цих інформаційних систем з системами інших регіонів.

Інформаційні системи охорони здоров'я проектувалися та розроблялися як системи 3 коротким життєвим циклом, а тому не дозволяють розглядати й аналізувати діяльність системи охорони здоров'я на великих часових інтервалах.

Установи системи охорони здоров'я акумулюють значні обсяги інформації, що є конфіденційною. Водночас питання інформаційної безпеки при проектуванні й експлуатації інформаційних систем охорони здоров'я історично не були пріоритетними.

Основною метою створення СICO3 є забезпечення ефективної інформаційної підтримки органів i організацій системи охорони здоров'я, а також громадян у рамках процесів управління медичною допомогою і їі безпосереднього надання. 
EICO3 дозволить забезпечити розв'язання комплексу завдань. Передусім, підвищиться ефективність управління охороною здоров'я на основі інформаційної підтримки завдань ухвалення рішень, прогнозування і планування витрат на надання медичної допомоги, а також контролю за дотриманням державних гарантій щодо об'єму і якості їі надання; підвищення якості надання медичної допомоги.

Буде забезпечено інформування населення щодо питань ведення здорового способу життя, профілактики захворювань і отримання медичної допомоги, а також якості обслуговування організацій з питань здійснення діяльності у сфері охорони здоров'я на основі забезпечення можливостей електронної взаємодії з відповідними уповноваженими органами.

Створення інформаційної системи в охороні здоров'я повинно грунтуватися на прийнятих у світі постулатах. Зокрема, передбачається, що забезпечуватиметься одноразове введення і багатократне використання первинної інформації, у тому числі електронних юридично значимих документів в якості основного джерела первинної інформації як для цілей практичної медицини, так і для цілей управління охороною здоров'я.

Має бути забезпечена сумісність (інтероперабельність) медичних інформаційних систем, що розробляються різними виробниками; інтеграція інформаційних ресурсів охорони здоров'я з інформаційними ресурсами інших відомств в частині спільного використання персональних даних і електронного обміну документами; нарешті, забезпечена система інформаційної безпеки і захисту персональних даних, у тому числі за рахунок використання електронних засобів ідентифікації лікаря і пацієнта (електронна карта лікаря, соціальна карта пацієнта).

Впроваджується централізоване управління розробкою, впровадженням і супроводом Системи на підставі єдиної технологічної політики, адаптованих до вітчизняних умов міжнародних стандартів в області медичної інформатики.

Загальна архітектура СICO3 повинна включати ряд модулів: прикладних систем учасників системи охорони здоров'я; єдиного інформаційного простору, що включає загальносистемні компоненти обчислювальної, телекомунікаційної й інтеграційної інфраструктури, бази цих і електронних документів, сервіси доступу й оброблення даних; зовнішній сегмент, що включає інформаційні системи недержавних організацій.

Модуль єдиного інформаційного простору ЄICO3 забезпечує збір і зберігання медичної інформації з використанням єдиної системи класифікації і кодування, надання цієї інформації і загальносистемних сервісів учасникам системи охорони здоров'я, а також зацікавленим особам відповідно до їх повноважень.

Основними постачальниками інформації для цього модуля виступають інформаційні системи медичних організацій різних форм власності.

Відмітимо, що у рамках модуля єдиного інформаційного простору створюються загальносистемні сервіси і додатки, що забезпечують: облік та ідентифікацію пацієнтів і медичного персоналу; персоніфікований облік наданої медичної допомоги, ведення електронного паспорта медичної організації і реєстру медичних працівників, ведення спеціалізованих регістрів по окремих нозологіях і категоріях громадян, отримання медичної допомоги (насамперед високотехнологічної), автоматизацію попередніх етапів медико-економічної експертизи, можливість аналітичного оброблення первинних даних, можливість централізованого збору й оброблення медичної статистики та проведення телемедичних консультацій.

На інфраструктурі державного та регіональних інформаційних ресурсів можуть розміщуватися портали, орієнтовані на надання інформаційних послуг i сервісів різним групам користувачів. Зберігання інформації, а також розміщення сервісів і додатків загального користування реалізується в територіально-розподіленому середовищі, що складається з регіональних інформаційних ресурсів і централізованого державного інформаційного ресурсу.

Взаємодія державних і регіональних інформаційних ресурсів, а також захищена взаємодія з учасниками системи охорони здоров'я здійснюється за допомогою галузевої єдиної захищеної інформаційно-телекомунікаційної мережі у сфері охорони здоров'я і медицини України. Підкреслимо, що агрегована інформація, а також загальносистемна нормативнодовідкова інформація знаходиться в Державному інформаційному ресурсі.

Зрозуміло, ЄICO3 забезпечує можливість за авторизованими запитами учасників системи охорони здоров'я автоматичне отримання медичної інформації, незалежно від іiі фізичного розміщення. Зовнішній сегмент $\mathrm{EICO} 3$ включає інформаційні системи недержавних організацій, а також приватних осіб, що надають громадянам і організаціям інформаційні послуги і сервіси в галузі охорони здоров'я на безоплатній або платній основі, у тому числі з використанням мережі Інтернет. Інформаційні ресурси і сервіси, доступні через системи зовнішнього сегмента, можуть бути використані при створенні компонентів сегмента прикладних систем учасників системи охо- 
рони здоров'я, а також сегмента єдиного інформаційного простору.

Висновки. 1. Необхідна докорінна зміна підходу до інформатизації охорони здоров'я, посилення координуючої ролі держави та створення єдиного інформаційного простору у сфері охорони здоров'я.

2. Пропонується нова єдина інформаційна система, що будується на 4 сегментах і певних принципах. Сeред сегментів виокремлюються: інформаційне відображення здоров'я населення; віддзеркалення медичної допомоги з позицій забезпечення її якості; управління трудовими ресурсами; відображення

\section{Лтература}

1. Григорович В. Р. Удосконалення управлінських механізмів державної підтримки системи охорони здоров'я в Україні. Електронне наукове фахове видання "Державне управління: удосконалення та розвиток"; включено до переліку наукових фахових видань України з питань державного управління (постанова президії ВАК України№> 2-05/3 від08.07.2009p.)

2. Козуліна С. О. Механізми державного управління діяльністю закладів охорони здоров'я (організаційно-правовий аспект) : автореф. дис. на здобуття наукового ступеня канд. наук з державного управління: 25.00 .02 (Одеський регіональний інститут державного управління Національної академії державного управління при Президентові України / С. О. Козуліна. - 2004. - С. 15. характеристик середовища, де мешкає громадянин (насамперед навколишнього середовища); віддзеркалення фармацевтичного забезпечення галузі й обгрунтованого застосування лікарських засобів. Серед базових принципів виділяються: обов'язкова реалізації дуальності (наявності стаціонарної та мобільної - медичного електронного паспорту громадянина України - частин) ЄICO3; створення та впровадження медичних стандартів (професійної мови, архетипів, шаблонів, класифікацій тощо); створення та впровадження інформаційних стандартів; забезпечення функціонування єдиного медичного простору.

3. Банчук М. В. Кадрова політика у галузі охорони здоров'я та рух вищої медичної освіти України до Європейського освітнього простору / М. В. Банчук, О. П. Волосовець, I. I. Фещенко [та ін.] // Медична освіта. - 2006. - № 2. C.6-14.

4. Мінцер О. П. Оцінювання якості медичної допомоги: стратегія, логіка і реальне втілення 2009 / О. П. Мінцер, Л. І. Усенко, Т. П. Іванова // Медичні перспективи. - 2010. T. XV, №1. - C. 139.

5. Апанасенко Г. Л. Охрана здоровья здоровых: постановка проблемы в Украине и России / Г. Л. Апанасенко // Український медичний часопис. - 2009. - №2 4. - С. 122 - 124. 